\title{
The Economics of Smart Defense
}

\author{
Keith Hartley *
}

\section{Introduction: Difficult Choices}

NATO’s “Smart Defense” proposal claims to be a new way of thinking about generating defense capabilities. It encourages allies to cooperate in developing, acquiring, and maintaining military capabilities. It means pooling and sharing capabilities, setting priorities, and coordinating efforts better. It involves member states not spending more but spending better; it is about specializing in what we do best and seeking multinational solutions to common problems. ${ }^{1}$

Smart Defense has economic dimensions that need to be clarified and assessed critically. We do not live in a world of "magic wand" economics, where declarations of intent miraculously lead to efficiency improvements in defense markets. Smart Defense cannot ignore the incentives and constraints that operate in defense markets at both the national and Alliance levels.

The financial and economic crisis of the past five years has meant cuts in national defense budgets, which have meant that nations cannot avoid the need for more and continuing difficult defense choices. Inefficiencies within member states' defense markets and within NATO have to be addressed. For each member state, budget pressures and rising input costs mean that, yet again, something has to go. The question is, What are the options and what goes?

Furthermore, defense budgets that have been cut in real terms still have to finance defense equipment, which is both costly and becoming costlier. For example, intergenerational cost growth on U.K. main battle tanks and combat aircraft was almost 6 percent. The unit cost of the Hunter fighter aircraft was $£ 4.6$ million in 1955, compared with today’s replacement, the Typhoon, at a unit cost of $£ 72$ million (2012 prices). Of course, the Typhoon is superior to the Hunter in terms of speed, weight, complexity, and capability. ${ }^{2}$ Such rising unit costs, which affect all nations, have led some commentators to forecast a future single-ship British Navy, a single-tank British Army, and a 'Starship Enterprise' for the Royal Air Force!

The defense economics problem is clear. Defense budgets-which are constant or falling in real terms, and subject to costly and rising equipment costs-mean that difficult defense choices cannot be avoided. National defense policies will have to consider a range of choices affecting equipment and personnel. While these choices will include

Keith Hartley is an Emeritus Professor of Economics at the University of York (U.K.).

1 Mikaela Blackwood, "How Smart is Smart Defense? A Review of NATO’s Smart Defense Proposals,” Connections: The Quarterly Journal 11:3 (Summer 2012): 85-93.

2 Neil Davies, A. Eager, M. Maier, and L. Penfold, Intergenerational Equipment Cost Escalation, DASA-DESA, Economic Working Paper Series No. 1 (London: U.K. Ministry of Defence, 2011). 
numbers of personnel and equipment, there are also substitution possibilities within equipment and personnel and between equipment and personnel.

Some of these choice problems can be avoided where there are inefficiencies in defense spending. The defense economics problem identifies the need to increase the efficiency of defense spending, and this applies to all member states and NATO. Of course, efficiency improvements also involve winners and losers: some of the interest groups that currently benefit from consuming inefficiency will lose from efficiency improvements. Examples of inefficiencies in defense markets include non-competitive procurement policies, preferential purchasing (e.g., buy-national policies), a failure to assess the efficiency of military units, and the duplication of armed forces and defense industries in NATO.

\section{Inefficiencies in NATO Defense Markets}

NATO is an inefficient organization for providing both armed forces and defense equipment. Inefficiency embraces opportunities for choosing an ideal or "socially-desirable" level of defense output and/or achieving the same defense output at a lower cost. Here, major problems arise, since defense markets are different. Compared with commercial markets, where there are large numbers of buyers and sellers, defense markets are dominated by governments as major or monopsony buyers, usually facing a national monopoly or oligopoly supplier of defense equipment. As major or only buyers, governments can determine the size of their national defense industry, its ownership, structure, and performance.

Governments are also the owners of their national armed forces. Such forces are publicly owned and publicly financed. They are state monopolies where their "managers" are not entrepreneurs governed by profit incentives and subject to the efficiency incentives of private capital markets reflected in take-over and bankruptcy threats. Instead, units in the armed forces are protected from competition; their managers (commanding officers) focus on increasing or protecting their budgets and are immune from costminimization and efficiency objectives; and, ultimately, senior commanders report to elected governments, who act as agents of the voters. In contrast, in private competitive markets, large numbers of private consumers determine society's preferred output of, say, motor cars and washing machines, and suppliers of these products are motivated by profitability, by rival firms, and by the "policing" behavior of private capital markets. Such incentives and market arrangements are lacking in the "non-market" for the armed forces (aircraft squadrons, army regiments, warships).

Also, in defense markets there are no obvious measures of defense output. Traditionally, defense outputs were measured on the basis of defense inputs (the principle that inputs equal outputs, which applies throughout the public sector). Some nations have improved on such conventions by identifying the defense capabilities purchased by its defense spending, but defense capabilities are not expressed in monetary terms in a way that easily allows them to be compared directly with defense spending (do the benefits of defense spending at least equal its costs?). 
A visitor from Mars would be astounded at the current arrangements for defense in NATO and the EU. Both organizations are characterized by inefficiencies in the provision of armed forces. There are massive duplications of national defense ministries, armies, navies, and air forces; duplication of training, military bases, and of logistics and repair organizations. Similarly, NATO and EU defense equipment markets are dominated by inefficiencies reflected in the duplication of costly defense R\&D spending and small-scale national production orders. For example, within NATO, there are eight competing types of combat aircraft (the F-15, F-16, F-18, F-22, and F-35, produced by the U.S.; the Swedish Gripen; the French Rafale; and the Eurofighter Typhoon) involving seven nations. Imagine the cost savings if these nations had selected only one type and combined their national production orders. The result would have been one R\&D bill and a total output for the eight nations of over 2,500 units of one type, leading to economies of scale and learning. However, while the most efficient solution would require all eight nations to purchase their combat aircraft from a single supplier, it is likely that the nations would require a multi-national collaboration. Such collaboration appears attractive economically, but it has been characterized by substantial inefficiencies reflecting work-sharing arrangements and duplication of procurement and industrial management organizations. ${ }^{3}$

\section{Improving Efficiency in NATO Defense Markets}

Economics offers some general principles for improving efficiency in NATO defense markets. These include:

- For economists, defense is a public good. Such goods are characterized by being non-rival and non-excludable (e.g., the provision of air defense for the U.K. is available to all its citizens), and these features apply within and between nations (e.g., NATO, the EU). For NATO, the strategic nuclear deterrent is an example of an alliance public good (peace is also a public good). ${ }^{4}$

- Public goods are characterized by free-riding behavior, both within a nation and between nations in a military alliance. Examples include the willingness of NATO nations to "free ride" on U.S. defense spending, and a focus on national rather than NATO interests when determining defense cuts (nations within an alliance will focus on burden-shifting rather than burden-sharing). ${ }^{5}$

3 Keith Hartley, White Elephants? The Political Economy of Multi-National Defence Projects (Brussels: New Direction, Foundation for European Reform, October 2012), available at http://newdirectionfoundation.org/content/white-elephants-political-economy-multi-nationaldefence-projects.

4 The strategic nuclear deterrent is non-rival among Allies, with the ability to deter an attack being independent of the number of Alliance members being protected. It is also non-excludable, since no Ally can be excluded from the consequences of using nuclear weapons against an aggressor.

5 The U.S. defense budget as a share of GDP is higher than the NATO average, but this is a misleading indicator, since U.S. defense spending is allocated to the defense of the U.S. mainland 
- The principle of self-interest. Smart Defense involves "spending better," but such changed behavior requires that individuals and groups be given appropriate incentives. Left to themselves, individuals or agents will use every opportunity to pursue their own interests, such as a desire for a quiet life, luxury offices, and attractive foreign travel. Economists regard this as a principal-agent problem, where there are difficulties for the owner or principal in monitoring an agent to whom decisions have been delegated. For example, an air commander might be given the task of bombing enemy targets, but is left with considerable discretion to interpret this objective (e.g., military, industrial, or city targets?). Typically, peacetime commanders of military units might be given fixed budgets to encourage cost-conscious behavior. But fixed budgets are often limited, since all major inputs and expenses are determined externally, which means that local commanders have only limited opportunities to economize (such as on catering, transport, and window cleaning costs for a military base). Also, even where commanders achieve cost savings, such savings accrue to the central organization, and ultimately to the national treasury, thus reducing the incentives for efficiency savings.

- The principle of international comparative advantage. Nations differ in their competitive ability to provide goods and services. Some nations are good at producing jet airliners; others are good at motor cars; and others are good at growing bananas. In defense, some nations have high labor costs, and their comparative advantage lies in advanced technology military forces and equipment, such as nuclear weapons and combat aircraft; other nations are low labor cost nations, and their comparative advantage lies in personnel-intensive armed forces and labor-intensive defense equipment (e.g. infantry, ammunition production).

- Efficiency requires private competitive markets: privately-owned firms operating in competitive markets subject to fixed price contracts leads to efficient outcomes. In principle, such markets are achievable for defense equipment, but they require that the definition of the market extends beyond the national dimension to allow foreign firms to bid for national defense contracts. However, importing defense equipment involves other risks-namely dependence on foreign suppliers and risks of re-supply in conflict, and foreign suppliers being unwilling (or prohibited by law) to supply the latest technology.

- While private competitive markets are feasible for defense equipment, their application to the armed forces raises much greater challenges. How would one introduce the notion of profitability for military units, or allowing the takeover of military units, or extend the use of contractors to full combat units? Nonetheless, some of these economic principles can be introduced into the armed forces, especially the use of private contractors competing for work traditionally undertaken by military units.

and the Pacific region as well as Europe. In contrast, most of NATO Europe's defense spending is for the defense of individual European nations. 
- There are extensive opportunities for applying the economic principle of substitution. For example, with respect to equipment, it is possible for imported equipment to replace nationally-produced equipment; within personnel, reserves can replace regulars, and private contractors can undertake some of the tasks usually performed by "in-house" military units. Between equipment and personnel, it is possible for capital to replace labor, just as aircraft substitute for soldiers, and the nuclear deterrent replaces conventional forces. Such substitution possibilities (and others) need to be part of NATO's Smart Defense policy.

\section{Applying These Principles: Some Examples}

Economic pressures on national defense budgets mean that radical defense choices have to be considered. ${ }^{6}$ These can be international, within an alliance, or national. But military cooperation between the twenty-eight member states of NATO is difficult and costly, since each member state has different national interests, different economies, and different defense budgets, each subject to the influence of its national military-industrialpolitical complex. Nonetheless, applying the above economic principles could offer efficiency improvements. Examples include:

- Identifying Alliance public goods and the opportunities for beneficial international collective action. One example would be the Alliance provision of an anti-ballistic missile defense system and a satellite surveillance network.

- Creating a defense equipment free trade area between member states of NATO. This would require member states to abandon preferential purchasing and support for their national defense industries. The EU has made a commitment to establishing a single market for defense equipment, but pressures from various national interest groups (aka protectionism for EU defense industries) will inevitably distort the final outcomes.

- Applying the principles of specialization by comparative advantage within NATO and the EU. Proposals for role specialization in NATO are not new, but these proposals are based on specialization by international comparative advantage, where comparative advantage is based on efficiency criteria (who are the lowest-cost suppliers of specific armed forces rather than some political-equity criteria for role specialization). Possible NATO examples include the U.K. and France providing aircraft carriers, with other European allies providing escort warships; or the U.K. providing amphibious forces, Germany providing tank units, and Turkey supplying infantry units. But such NATO specialization cannot be left to market forces, since there is no market for the military units of a nation's armed forces. Instead, NATO central headquarters would have to allocate specialized military roles to partner nations based on their comparative advantage. Sovereign nations will be unwilling to

6 EU nations might be subject to a major external shock if the United States decided to withdraw from NATO to focus on the Pacific region. Such a shock effect might lead to EU nations developing a more efficient defense policy. 
accept NATO declarations on the size, structure, and role of their national military forces. Defense is about protecting the security of a nation's citizens, its assets, and its national interests, and no nation will be willing to delegate that function to an unelected international military alliance.

- In the absence of military specialization, there is scope for exploring a greater use of pooling and sharing military resources and capabilities between NATO member states, as outlined in its Smart Defense policy. Pooling and sharing costly assets, say, between two member states, might be a first step towards role specialization. Examples of beneficial sharing might include France and the U.K. sharing their nuclear deterrents (e.g., two boats per nation rather than each nation owning four boats); sharing satellites; sharing training and military bases; or sharing their air tanker and air transport fleets and maritime air patrol capabilities. Sharing can be extended to other nations within NATO - for example, some nations specialize in providing peace-support forces.

Inevitably, there are two major issues with sharing and pooling proposals, and hence with Smart Defense. The first is the issue of ownership and funding (either via money or in-kind contributions). Who will own the specialized asset? Will they be willing to share use of the asset? How will its acquisition and operation costs be shared between the potential users? The private sector "solves" these problems through "club" arrangements, where members join a club that is economically attractive compared with the option of no club (e.g., clubs for angling, golf, swimming and tennis, where individuals would not be able to afford such facilities). Second, the key issue of trust, which is difficult to formulate into a legally-binding international contract. National contracts are difficult and costly to enforce, but the difficulties and costs are much greater for international contracts where there is no enforcement agency equivalent to national courts (even if trust could be defined legally). Here, the central issue is whether in a conflict the partners will in fact show up to help. For example, some partner nations might be unwilling to commit their national military capabilities to be used in a conflict involving another particular nation. For instance, Spain might be unwilling to provide support to the U.K. for a conflict involving the Falkland Islands and Argentina. If ownership, funding, and trust continue to create barriers to efficiency improvements in NATO defense markets, then nations will have to bear the consequences: all the adjustments to the defense economics problem will be confined to the level of the nation-state.

There are further barriers to improving efficiency in NATO and national defense markets represented by each nation's military-industrial-political complex. These include agents in national defense ministries, the armed forces, producer interest groups, and elected politicians and national governments. Each of these agents will pursue its self-interest, including budget-maximization for bureaucracies and the armed forces, rent-seeking by defense contractors, and vote-maximization by politicians. Such diverse behavior by different interest groups is unlikely to lead to efficient outcomes in NATO and national defense markets. Indeed, Smart Defense policies might lead to perverse outcomes. For example, the apparent economic benefits of multi-national collaboration 
for equipment programs might lead to major collaboration inefficiencies as each partner nation seeks portions of the work that protect and benefit its national defense industry.

\section{Conclusion}

Nations cannot avoid the defense economics problem reflected in the continued need to make difficult defense choices. Typically, these choices will be made on the basis of national interests, and they will reflect the influence of national military, industrial, and political pressure groups. Prospective defense cuts will be met with myths, emotion, and special pleading. Examples include claims that "force $\mathrm{X}$ is absolutely essential for national defense," or that "the loss of capability Y means that we shall no longer be able to intervene in some specific part of the world," or the fear that "we are losing our world influence." These claims need to be subject to critical appraisal, including an assessment of their costs.

Smart Defense also needs to recognize and apply the economic principle of substitution: the idea that there are alternative means of providing defense. Duplication of armed forces is costly. Typically, the private sector uses capital, including technology in the form of computers and machinery, to replace labor. Applied to defense, nations need to explore the extent to which capital-intensive armed forces can replace labor-intensive forces. The price of introducing new equipment might be labor substitutions either within each service or between services. Examples include the nuclear deterrent replacing conventional forces, and the capital-intensive air force and navy replacing the laborintensive army. Other examples of possible substitutions include attack helicopters replacing tanks; maritime patrol aircraft replacing naval frigates in anti-submarine roles; UAVs and cruise missiles replacing manned strike and manned maritime air patrol capabilities; and reserves replacing regulars, including the greater use of reservists in flying roles.

NATO's Smart Defense initiative cannot ignore the market and non-market arrangements for supplying defense equipment and military forces. These are political markets dominated by national governments and their military-industrial-political complexes. Ignoring the economic aspects of Smart Defense will confine the initiative to the same sidelines as previous NATO policies (such as that on standardization). 
THE QUARTERLY JOURNAL

\section{Bibliography}

Blackwood, Mikaela. "How Smart is Smart Defense? A Review of NATO's Smart Defense Proposal." Connections: The Quarterly Journal 11, no. 3 (2012): 85-93.

Davies, Neil, A. Eager, M. Maier, and L. Penfold. Intergenerational Equipment Cost Escalation In DASA-DESA, Economic Working Paper Series. London: U.K.: Ministry of Defence, 2011.

Hartley, Keith. White Elephants? The Political Economy of Multi-National Defence Projects. Brussels: New Direction, Foundation for European Reform, 2012. 